DOI: https://doi.org/10.24127/ajpm.v8i2.2057

\title{
DISKALKULIA (KESULITAN MATEMATIKA) BERDASARKAN GENDER PADA SISWA SEKOLAH DASAR DI KOTA MALANG
}

\author{
Firda Alfiana Patricia ${ }^{1}$, Kenys Fadhilah Zamzam² \\ ${ }^{1,2}$ Pendidikan Matematika, IKIP Budi Utomo Malang \\ E-mail: firdaalfianapatricia1985@gmail.com ${ }^{\text {l) }}$ \\ kenysfz@gmail.com ${ }^{2}$
}

Received 25 June 2019; Received in revised form 15 October 2019; Accepted 28 October 2019

\begin{abstract}
Abstrak
Penelitian ini bertujuan untuk mendeskripsikan kesulitan siswa di sekolah dasar dalam memahami pelajaran matematika yang biasa disebut sebagai diskalkulia yang ditinjau berdasarkan gender. Instrumen penelitian berupa sebuah tes yang terdiri dari 8 pertanyaan bersifat uraian yang mengacu pada indikator diskalkulia siswa sekolah dasar yaitu kemampuan mengurutkan angka dari yang nilainya lebih besar atau lebih kecil, kemampuan memilih angka yang mempunyai nilai paling banyak atau paling sedikit, dan kemampuan menyatakan hasil dari sebuah operasi bilangan. Jenis penelitian ini adalah deskriptif kualitatif. Subjek dalam penelitian ini adalah siswa kelas 3 sekolah dasar sebanyak 150 siswa yang terdiri dari 80 siswa laki-laki dan 70 siswa perempuan. Data yang dikumpulkan dalam penelitian ini adalah data tertulis yaitu hasil pekerjaan siswa sedangkan data tidak tertulis adalah hasil pengamatan dan wawancara. Pada analisis data, dihitung jumlah jawaban bernilai salah dari setiap nomor tes kemudian digolongkan sesuai dengan jenis diskalkulia yang sesuai dan diakhiri dengan wawancara untuk mengetahui kesulitannya. Hasil tes menunjukkan bahwa ditemukan 2 dari 9 jenis diskalkulia yaitu diskalkulia proctagnostic dan diskalkulia indiagnostic. Diskalkulia proctagnostic merupakan kesulitan belajar matematika dalam membandingkan dan mengurutkan bilangan. Diskalkulia indiagnostic merupakan kesulitan belajar matematika dalam memahami konsep operasi bilangan. Berdasarkan hasil jawaban siswa menunjukkan bahwa persentase jawaban yang paling banyak ditemukan kekeliruan adalah jawaban dari siswa perempuan.
\end{abstract}

Kata kunci: diskalkulia; gender.

\begin{abstract}
This study aims to describe the difficulties of students in elementary schools in understanding mathematics which are commonly referred to as discalculia which are reviewed by gender. The research instrument was in the form of a test consisting of 8 descriptive questions that refer to indicators of dyscalculia in elementary school students, the ability to sort numbers from larger or smaller values, the ability to choose numbers that have the most or least value, and the ability to express results from a number operation. This type of research is descriptive qualitative. Subjects in this study were 3rd grade elementary school students of 150 students consisting of 80 male students and 70 female students. The data collected in this study is written data that is the result of student work while the unwritten data is the result of observations and interviews. In the analysis of the data, the number of wrong answers from each test number was calculated and then classified according to the appropriate type of dyscalculia and ended with an interview to find out the difficulty. The test results showed that 2 out of 9 dyscalculia types were found, proctagnostic dyscalkulia and indiagnostic dyscalculia. Proctagnostic dyscalculia is the difficulty of learning mathematics in comparing sort numbers. Indiagnostic dyscalculia is a difficulty learning mathematics in understanding the concept of number operations. Based on the results of the students' answers, it shows that the percentage of the answers that are most found to be errors is the answers of the female students.
\end{abstract}

Keywords: dyscalculia; gender. 
DOI: https://doi.org/10.24127/ajpm.v8i2.2057

\section{PENDAHULUAN}

Anak merupakan salah satu karunia tak ternilai dari Sang Maha Pencipta. Setiap anak memiliki kemampuan yang berbeda-beda, mereka pandai dalam bidangnya masing-masing menyesuaikan bakat dan minatnya. Namun ada kalanya ditemukan anak yang mengalami kesulitan dalam belajar. Hal ini terkadang tidak disadari oleh orang tua maupun guru yang mengajar di sekolah. Lantas dengan serta merta label "tidak pandai" dicap kepada anak yang mengalami kesulitan belajar tersebut.

Kesulitan dalam belajar merupakan kondisi yang wajar dialami oleh setiap siswa. Kesulitan belajar tersebut akan bertambah parah jika guru belum memahami bentuk-bentuk dari kesulitan belajar dan bagaimana penanganan yang sesuai dengan kesulitan belajar yang dialami oleh siswanya. Akibat yang ditimbulkan dari kesulitan belajar adalah terhambatnya proses belajar siswa tersebut, tidak jarang ada siswa harus mengulang kelas hanya karena mengalami kesulitan belajar secara akademik. Salah satu bentuk kesulitan belajar siswa yang berkaitan dengan akademik adalah kesulitan dalam belajar matematika. Kesulitan belajar matematika ini merupakan kesulitan belajar yang paling banyak ditemukan pada siswa sekolah dasar. Berdasarkan hasil penelitian yang dilakukan oleh (Kenedi, Helsa, Ariani, Zainil, \& Hendri, 2019) membuktikan bahwa kemampuan koneksi matematika pada siswa sekolah dasar dalam menyelesaikan permasalahan matematika masih rendah. Penelitian yang dilakukan oleh (Raharjo, Kawuryan, \& Ahyani, 2011) untuk mengidentifikasi learning disability ditemukan 13 anak kelas 3 sekolah dasar yang mengalami diskalkulia di kabupaten Kudus. Untuk menentukan hasil penelitian yang dilakukan tersebut menggunakan teknik observasi, tes IQ dan tes kemampuan belajar. Kemudian di Jombang ditemukan sebanyak 16 siswa diantaranya 10 laki-laki dan 6 perempuan yang mengalami kesulitan dalam berhitung menurut hasil penelitian (Bintoro \& Wijiastuti, 2016) dengan teknik pengumpulan data menggunakan tes, observasi, dan dokumentasi.

Berdasar pada penemuanpenemuan tersebut semestinya sebagai pendidik diharapkan dapat memahami kesulitan siswanya dalam matematika. Salah satu cara yaitu dapat dicoba dengan mengadakan penilaian kepada setiap siswa sehingga dapat diketahui apakah siswa tersebut mengalami kesulitan atau tidak. Hal itu bertujuan agar anak yang mengalami kesulitan berhitung tidak mengalami kendala dalam proses belajar dan dapat diberikan penanganan yang tepat untuk anak yang mengalami kesulitan dalam matematika tersebut. Semakin dini ditemukan anak yang mengalami kesulitan berhitung di sekolah dasar regular maka akan lebih cepat anak tersebut mendapatkan penanganan dari guru (Bintoro \& Wijiastuti, 2016). Menurut (Trieni, 2018) pada pembelajaran matematika harus disesuaikan dengan jenis dan penyebab kesulitan belajar siswa juga lebih bersifat individual sehingga siswa dapat belajar sesuai dengan tingkat kemampuan masing-masing.

Kesulitan anak dalam belajar matematika sering disebut sebagai diskalkulia. Siswa yang mengalami diskalkulia merupakan representasi dari lemahnya penggunaan strategi pemecahan masalah siswa yang belum matang atau tidak efisien, sehingga 
siswa dengan gangguan diskalkulia tidak dapat belajar aritmetika dengan baik, sehingga memorinya tidak dapat mengingat dengan lancar (Azhari, 2017).

(Sudha \& Shalini, 2014) menyatakan bahwa diskalkulia merupakan istilah luas untuk kesulitan dalam belajar matematika. Hal ini mencakup semua jenis permasalahan dalam matematika seperti ketidakmampuan untuk memahami arti bilangan sampai dengan ketidakmampuan untuk menerapkan prinsip matematika dalam memecahkan masalah. Salah satu faktor penyebabnya selain kurang berhasilnya proses belajar mengajar di kelas juga terjadi karena disfungsi hemisfer kanan yang menyebabkan kesulitan dalam memahami sifat kuantitas, masalah pembelajaran spasial (misalnya, memahami dan menggunakan nilai tempat) dan menggunakan pengetahuan aritmatika untuk menyelesaikan masalah kehidupan nyata sedangkan disfungsi hemisfer kiri menyebabkan kesulitan memahami makna abstrak bilangan, urutan operasi numerik dan matematika.

Indikator siswa dalam penelitian ini yang mengalami diskalkulia pada usia sekolah dasar dimodifikasi berdasarkan (Iftayani, 2018) yang dapat dilihat dari pemahaman bilangan dan jumlah yang meliputi kemampuan mengurutkan bilangan dari yang nilainya lebih besar atau lebih kecil dan kemampuan memilih bilangan yang mempunyai nilai paling banyak atau paling sedikit. Pemahaman materi dasar matematika yang meliputi kemampuan menyatakan hasil dari sebuah operasi penjumlahan, operasi pengurangan, operasi perkalian, dan operasi pembagian.
Terdapat jenis-jenis diskalkulia yang menurut (Nfon, 2016) diklasifikasikan sebagai berikut :

1) Diskalkulia kuantitatif adalah kesulitan keterampilan menghitung dan mengkalkulasi;

2) Diskalkulia kualitatif adalah kesulitan menguasai keterampilan yang diperlukan untuk suatu operasi melibatkan penambahan, pengurangan, perkalian, pembagian dan akar kuadrat;

3) Diskalkulia intermediate merupakan ketidakmampuan siswa untuk mengoperasikan simbol atau bilangan, apalagi simbol $<,>, t,-, x$, $\div$ V. Ketika jumlahnya lebih besar dari 100.000.000 siswa akan membutuhkan bantuan untuk memanipulasi atau membacanya;

4) Diskalkulia verbal, dapat membaca dan menulis bilangan, tetapi tidak dapat paham tentang makna dari bilangan, mengingat nama bilangan, atau mengenali bilangan ketika diucapkan oleh orang lain;

5) Diskalkulia practognostic adalah kesulitan dalam memanipulasi halhal secara matematis, misalnya membandingkan bilangan untuk melihat mana yang lebih kecil atau lebih besar dan mengalami kesulitan bekerja dengan kuantitas, volume atau persamaan yang sebenarnya secara praktis;

6) Diskalkulia leksikal, dapat membaca digit tunggal, tetapi tidak dapat mengingat tempat mereka dalam jumlah yang lebih besar;

7) Diskalkulia grafis adalah kesulitan siswa dalam menulis simbol dan bilangan matematika;

8) Diskalkulia indiagnostik merupakan ketidakmampuan untuk mengingat ide atau konsep matematika setelah mempelajarinya; 
9) Diskalkulia operasional adalah kesulitan dalam melakukan operasi dan perhitungan aritmatika, memiliki masalah untuk melakukan perhitungan yang membutuhkan memanipulasi angka dan simbol matematika.

Selain perbedaan kemampuan matematika di dalam kelas, perbedaan lain yang juga harus menjadi perhatian guru adalah tentang gender. (Rahman, 2016) menyebutkan bahwa gender merupakan perbedaan peran, fungsi, sifat, kedudukan, tanggung jawab dan hak perilaku baik perempuan maupun laki-laki yang dibentuk, dibuat, dan disosialisasikan oleh norma, adat kebiasaan dan kepercayaan masyarakat setempat. Perbedaan gender tersebut tidak dapat dipungkiri oleh siapapun. Sebagai pendidik memang harus menyadari perbedaan tersebut agar dapat membuat pembelajaran siswa berhasil.

Perbedaan gender mempengaruhi cara siswa belajar. Menurut (Nasser, 2016) anak perempuan lebih kuat di bidang verbal dan emosi, sedangkan anak laki-laki cenderung lebih menuju kegiatan kinestetik dan visual-spasial. Meskipun terdapat perbedaan yang menunjukkan keunggulan siswa laki-laki pada ketrampilan spatial, siswa perempuan lebih unggul dalam kemampuan komunikasi (verbal) matematis, lebih termotivasi, terorganisasi dalam belajar (MZ, 2018). Siswa laki-laki secara substansial memiliki sikap yang lebih positif dan lebih tinggi tingkat partisipasinya terhadap matematika daripada siswa perempuan (Hall, 2012). Banyak orang meyakini bahwa anak laki-laki lebih baik dalam hal matematika, lebih mampu dengan komputer, dan lebih cocok untuk bekerja di industri komputer dibandingkan anak perempuan (Leder, Forgasz, \& Jackson, 2014). Dari beragam perbedaan belajar antara anak perempuan dan laki-laki tersebut diharapkan guru dapat menyesuaikan proses pembelajaran yang sesuai agar hasil yang didapatkan akan maksimal.

Berdasarkan hasil observasi pendahuluan pada sekolah dasar di kota Malang, guru kelas 3 menyatakan bahwa ada siswa yang masih belum memiliki kemampuan yang matang dalam berhitung sehingga guru menjadi bingung dikarenakan siswa yang lain sudah mampu untuk menuju materi selanjutnya yang lebih sulit. Dikhawatirkan siswa yang mengalami kesulitan dalam belajar matematika ini akan tertinggal dari teman-temannya yang lain. Untuk itulah dengan adanya penelitian ini diharapkan dapat membantu guru untuk mengetahui jenis kesulitan belajar matematika yang dialami oleh siswanya. Dengan demikian dapat ditentukan bahwa tujuan dari penelitian ini adalah untuk mendeskripsikan kesulitan belajar matematika atau yang biasa disebut dengan diskalkulia yang dialami oleh siswa sekolah dasar dengan membedakan gendernya. Hasil dari penelitian ini diharapkan dapat membantu guru untuk mengetahui jenis diskalkulia atau kesulitan belajar siswanya dalam belajar matematika sehingga guru dapat memberikan latihan soal yang sesuai dengan jenis diskalkulia yang ditemukan.

\section{METODE PENELITIAN}

Jenis penelitian ini merupakan deskriptif kualitatif. Pelaksanaan penelitian ini bertempat di empat sekolah dasar di kota Malang yang mewakili masing-masing kecamatan diantaranya adalah Sekolah Dasar Anak 
Saleh, Sekolah Dasar Plus Al-Kautsar, Sekolah Dasar Islamic Global School, dan Sekolah Dasar Kartika IV-1. Subjek dalam penelitian ini adalah siswa sekolah dasar kelas 3 sebanyak 150 anak yang terdiri dari 80 siswa laki-laki dan 70 siswa perempuan.

Sesuai dengan jenis penelitian ini yang merupakan deskriptif kualitatif maka instrumen kunci berperan dalam pengambilan dan pengolahan data yang kemudian melaksanakan penyimpulan data. Data yang dikumpulkan dalam penelitian ini berupa data tertulis dan tidak tertulis. Data tertulis merupakan hasil pekerjaan siswa dalam menyelesaikan tes tersebut sedangkan data tidak tertulis merupakan hasil pengamatan dan wawancara. Dalam analisis data, dihitung jumlah jawaban yang salah pada setiap nomor tes. Kemudian digolongkan sesuai dengan jenis diskalkulia yang sesuai dan menentukan jenis diskalkulia yang ditemukan. Setelah itu dilakukan wawancara dengan subjek terpilih yang mewakili setiap nomor tes dan mewakili masing-masing gender yang sesuai dengan rekomendasi dari guru yang bersangkutan untuk mengetahui kesulitan yang dialami oleh subjek dalam belajar matematika. Untuk itulah dipilih 6 siswa laki-laki dan 6 siswa perempuan untuk melakukan wawancara. Pemilihan subjek terpilih didasarkan pada kemampuan komunikasi yang baik.

Dalam proses pengambilan data, digunakan instrumen penelitian yang dikembangkan berdasarkan indikator siswa yang mengalami diskalkulia pada usia sekolah dasar, maka instrumen dalam penelitian ini diuraikan dalam Tabel 1.
Tabel 1. Instrumen yang disesuaikan dengan indikator siswa diskalkulia

\begin{tabular}{|c|c|c|}
\hline No & Indikator & Instrumen \\
\hline 1. & $\begin{array}{l}\text { Mengurutkan } \\
\text { bilangan dari yang } \\
\text { terbesar }\end{array}$ & $\begin{array}{l}\text { Mengurutkan } \\
2571,5721, \\
1572,7521 \text { dari } \\
\text { yang terbesar }\end{array}$ \\
\hline 2. & $\begin{array}{l}\text { Mengurutkan } \\
\text { bilangan dari yang } \\
\text { terkecil }\end{array}$ & $\begin{array}{l}\text { Mengurutkan } \\
3896,8369, \\
9836,6983 \text { dari } \\
\text { yang terkecil }\end{array}$ \\
\hline 3. & $\begin{array}{l}\text { Menyebutkan } \\
\text { bilangan yang } \\
\text { mempunyai nilai } \\
\text { paling besar }\end{array}$ & $\begin{array}{l}\text { Menyebutkan } \\
\text { nilai paling besar } \\
\text { dari } 2751,5217 \text {, } \\
1725,7251\end{array}$ \\
\hline 4. & $\begin{array}{l}\text { Menyebutkan } \\
\text { bilangan yang } \\
\text { mempunyai nilai } \\
\text { paling kecil }\end{array}$ & $\begin{array}{l}\text { Menyebutkan } \\
\text { nilai paling kecil } \\
\text { dari } 6893,9386 \text {, } \\
3869,8963\end{array}$ \\
\hline 5. & $\begin{array}{l}\text { Menyelesaikan } \\
\text { operasi hitung } \\
\text { penjumlahan tanpa } \\
\text { teknik menyimpan. }\end{array}$ & $\begin{array}{l}\text { Menyelesaikan } \\
\text { operasi hitung } \\
\text { dari } 125+152= \\
\ldots\end{array}$ \\
\hline 6. & $\begin{array}{l}\text { Menyelesaikan } \\
\text { operasi hitung } \\
\text { pengurangan tanpa } \\
\text { teknik meminjam. }\end{array}$ & $\begin{array}{l}\text { Menyelesaikan } \\
\text { operasi hitung } \\
\text { dari } 152-125= \\
\ldots\end{array}$ \\
\hline 7. & $\begin{array}{l}\text { Menyelesaikan } \\
\text { operasi hitung } \\
\text { penjumlahan dengan } \\
\text { teknik menyimpan. }\end{array}$ & $\begin{array}{l}\text { Menyelesaikan } \\
\text { operasi hitung } \\
\text { dari } 196+169= \\
\ldots\end{array}$ \\
\hline 8. & $\begin{array}{l}\text { Menyelesaikan } \\
\text { operasi hitung } \\
\text { pengurangan dengan } \\
\text { teknik meminjam. }\end{array}$ & $\begin{array}{l}\text { Menyelesaikan } \\
\text { operasi hitung } \\
\text { dari } 183-138= \\
\ldots\end{array}$ \\
\hline
\end{tabular}

\section{HASIL PENELITIAN DAN PEMBAHASAN}

Berdasarkan hasil tes yang sudah dikerjakan oleh siswa dari 8 soal tes yang diberikan ditemukan 24 siswa dengan rincian 14 siswa perempuan dan 10 siswa laki-laki yang menjawab tes tersebut tidak sesuai dengan jawaban yang benar. Rincian hasil tes akan diuraikan pada Tabel 2. 
DOI: https://doi.org/10.24127/ajpm.v8i2.2057

Tabel 2. Rincian kekeliruan jawaban

\begin{tabular}{cccc}
\hline $\begin{array}{c}\text { No. } \\
\text { Soal } \\
\text { Tes }\end{array}$ & $\begin{array}{c}\text { Jumlah } \\
\text { siswa } \\
\text { perempuan }\end{array}$ & $\begin{array}{c}\text { Jumlah } \\
\text { siswa } \\
\text { laki-laki }\end{array}$ & Total \\
\hline 1. & 3 & 1 & 4 \\
2. & 1 & 1 & 2 \\
3. & 3 & 1 & 4 \\
4. & 4 & 1 & 5 \\
5. & 0 & 0 & 0 \\
6. & 0 & 0 & 0 \\
7. & 2 & 3 & 5 \\
8. & 1 & 3 & 4 \\
Total & 14 & 10 & 24 \\
\hline
\end{tabular}

Dari 8 soal tes yang diberikan, siswa melakukan kekeliruan dalam menjawab soal dan ditemukan pada soal tes nomer 1, 2, 3, 4, 7, dan 8. Berikut ini uraian kekeliruan jawaban yang ditemukan pada siswa. Kekeliruan jawaban yang ditemukan juga seragam artinya tidak terdapat perbedaan yang mencolok pada kesulitan belajar matematika yang dialami oleh siswa perempuan maupun laki-laki. Pertanyaan dan jawaban yang bernilai benar untuk soal tes nomor 1 ditunjukkan oleh Tabel 3.

Tabel 3. Soal dan jawaban tes nomor 1

\begin{tabular}{cll}
\hline $\begin{array}{c}\text { No. } \\
\text { Soal } \\
\text { Tes }\end{array}$ & Pertanyaan & Jawaban \\
\hline 1 & Urutkan & \\
& bilangan & $2521,5721,1572$ \\
& 2571,5721, & \\
& 1572,7521 & \\
& dari yang & \\
& terbesar! & \\
\hline
\end{tabular}

Soal tes nomer 1 meminta siswa mengurutkan bilangan 2571, 5721, 1572, dan 7521 dari nilai yang terbesar, tetapi ada 4 siswa yang terdiri dari 3 siswa perempuan dan 1 siswa laki-laki yang keliru dalam menjawab sehingga tidak menjawab sesuai dengan jawaban yang benar. Berdasarkan temuan kekeliruan jawaban tersebut, dilakukan wawancara kepada subjek yang jawabannya keliru agar bisa didapatkan informasi tentang kesulitan dalam mempelajari pengurutan bilangan tersebut. Pada soal tes nomer 1 ini subjek yang diwawancara ada 2 siswa yang terdiri dari 1 siswa perempuan dan 1 siswa laki-laki. Subjek tersebut kemudian diberi kode A1 untuk mewakili siswa perempuan dan kode A2 untuk mewakili siswa laki-laki.

Dari hasil wawancara dengan subjek A1 didapatkan informasi bahwa ketika mengurutkan bilangan tersebut subjek A1 kebingungan dalam membandingkan bilangan mana yang nilainya lebih besar. Dengan kata lain subjek A1 kurang matang dalam memahami perbandingan bilangan yang menyebabkan subjek A1 mengalami kesulitan dalam mengurutkan keempat bilangan tersebut dari yang terbesar. Subjek A1 selalu terbolak balik dalam memahami makna bilangan yang lebih besar tersebut. Kemudian wawancara dilanjutkan kepada subjek A2. Informasi yang diperoleh, subjek A2 mengurutkan keempat bilangan tersebut dari arah yang berlawanan yaitu yang mempunyai nilai paling besar diletakkan di urutan paling belakang. Jadi subjek A2 keliru membaca pernyataan tersebut karena subjek A2 fokus melihat bilangan yang lebih besar.

Dari subjek A1 ditemukan bahwa terjadi kesulitan dalam mengurutkan bilangan, sedangkan pada subjek A2 keliru dalam memahami konteks pernyataan. Subjek A1 menjawab soal tes nomer 1 seperti itu karena kesulitan dalam mengurutkan nilai bilangan karena kurang matang dalam memahami urutan bilangan. Dengan kesulitan belajar matematika ini jenis diskalkulia yang sesuai dengan 
DOI: https://doi.org/10.24127/ajpm.v8i2.2057

temuan yaitu diskalkulia practognostic. Pertanyaan dan jawaban yang bernilai benar untuk soal tes nomor 2 ditunjukkan oleh Tabel 4.

Tabel 4. Soal dan jawaban tes nomor 2

\begin{tabular}{clc}
\hline $\begin{array}{c}\text { No. } \\
\begin{array}{c}\text { Soal } \\
\text { Tes }\end{array}\end{array}$ & \multicolumn{1}{c}{ Pertanyaan } & Jawaban \\
\hline 2 & Urutkan bilangan & 3896,6983, \\
& 3896, 8369, 9836, & 8369,9836 \\
& 6983 dari yang & \\
& terkecil ! & \\
\hline
\end{tabular}

Soal tes nomer 2 meminta siswa mengurutkan bilangan 3896, 8369, 9836, dan 6983 dari yang terkecil yang seharusnya dijawab dengan 3896 , 6983, 8369, 9836. Tetapi dari hasil jawaban siswa ditemukan ada 2 siswa yang terdiri dari 1 siswa perempuan dan 1 siswa laki-laki yang keliru dalam mengurutkan bilangan-bilangan tersebut dari yang terkecil. Berdasarkan temuan tersebut, peneliti melakukan wawancara dengan subjek yang melakukan kekeliruan jawaban pada soal tes nomor 2 diantaranya 1 siswa perempuan dan 1 siswa laki-laki. Kedua subjek ini memberikan jawaban yang keliru pada soal tes nomer 2. Untuk subjek siswa perempuan dikodekan dengan subjek B1 sedangkan subjek siswa laki-laki dikodekan dengan subjek B2. Dari hasil wawancara dengan subjek B1 dan subjek B2 ditemukan penyebab yang sama yaitu bingung ketika membandingkan bilangan mana yang besar dan mana yang kecil. Kedua subjek tersebut bingung membandingkan keempat bilangan yang terdiri dari 4 digit tersebut.

Hasil wawancara dengan subjek B1 dan subjek B2 menunjukkan kekeliruan jawaban yang sama dan penyebab yang sama yaitu kurang matang dalam memahami konsep urutan bilangan. Hal ini menunjukkan bahwa subjek B1 dan subjek B2 teridentifikasi mengalami diskalkulia practognostic. Pertanyaan dan jawaban yang bernilai benar untuk soal tes nomor 3 ditunjukkan oleh Tabel 5.

Tabel 5. Soal dan jawaban tes nomor 3

\begin{tabular}{clcc}
\hline $\begin{array}{c}\text { No. } \\
\text { Soal } \\
\text { Tes }\end{array}$ & \multicolumn{1}{c}{ Pertanyaan } & Jawaban \\
\hline 3 & Sebutkan & bilangan & 7251 \\
& yang & nilainya & \\
& paling besar dari & \\
& $2751, \quad 5217$, 1725, & \\
& $7251 !$ & \\
\hline
\end{tabular}

Soal tes nomer 3 meminta siswa untuk menyebutkan bilangan terbesar dari 2751, 5217, 1725, 7251. Jawaban yang sesuai dengan pertanyaan tersebut adalah 7251. Tetapi hasil temuan yang didapatkan, terdapat 4 siswa diantaranya 3 siswa perempuan dan 1 siswa laki-laki yang keliru dalam menentukan bilangan paling besar dari keempat bilangan tersebut.

Dari hasil temuan tersebut, dilakukan wawancara kepada 2 subjek yang keliru dalam menjawab masingmasing 1 siswa perempuan dan 1 siswa laki-laki. Subjek tersebut kemudian dikodekan dengan $\mathrm{C} 1$ untuk siswa perempuan dan C2 untuk siswa lakilaki. Hasil wawancara dengan subjek $\mathrm{C} 1$ dan subjek $\mathrm{C} 2$ ditemukan alasan yang sama yaitu bingung membandingkan bilangan. Hal tersebut terjadi karena subjek $\mathrm{C} 1$ dan subjek $\mathrm{C} 2$ kurang matang pada konsep urutan bilangan sehingga terjadi diskalkulia practognostic. Pertanyaan dan jawaban yang bernilai benar untuk soal tes nomor 4 ditunjukkan oleh Tabel 6. 
DOI: https://doi.org/10.24127/ajpm.v8i2.2057

Tabel 6. Soal dan jawaban tes nomor 4

\begin{tabular}{clcc}
\hline $\begin{array}{c}\text { No. } \\
\text { Soal } \\
\text { Tes }\end{array}$ & \multicolumn{1}{c}{ Pertanyaan } & Jawaban \\
\hline 4 & Sebutkan & bilangan & 3869 \\
& yang & nilainya & \\
& paling kecil dari & \\
& $6893,9386,3869$, & \\
& $8963 !$ \\
\hline
\end{tabular}

Soal tes nomer 4 meminta siswa untuk menyebutkan bilanga terkecil dari 6893, 9386, 3869, da 8963. Jawaban yang sesuai denga pertanyaan tersebut adalah 3869. Da hasil temuan yang diperoleh, terdapat siswa diantaranya 4 siswa perempua dan 1 siswa laki-laki yang keliru dalas menentukan bilangan paling kecil da keempat bilangan tersebut.

Berdasarkan hasil temua tersebut, dilakukan wawancara kepada subjek yang keliru dalam menjawa masing-masing 1 siswa perempuan da 1 siswa laki-laki. Subjek tersebı kemudian dikodekan dengan D1 untu siswa perempuan dan D2 untuk sisu laki-laki. Hasil wawancara denga subjek D1 dan subjek D2 ditemuka alasan yang juga sama dengan soal te nomor sebelumnya yaitu kedua subje tersebut kebingungan ketik membandingkan bilangan. Hal tersebı menunjukkan bahwa subjek D1 da subjek D2 kurang matang pada konse urutan bilangan sehingga terjar diskalkulia practognostic. Pertanyaa dan jawaban yang bernilai benar untu soal tes nomor 7 ditunjukkan oleh Tabı 7.

Tabel 7. Soal dan jawaban tes nomor 7

\begin{tabular}{clc}
\hline $\begin{array}{c}\text { No. } \\
\text { Soal } \\
\text { Tes }\end{array}$ & \multicolumn{1}{c}{ Pertanyaan } & Jawaban \\
\hline 7 & $\begin{array}{l}\text { Selesaikan } \\
\text { operasi hitung } \\
\text { dari } 196+169 !\end{array}$ & \\
\hline
\end{tabular}

Soal tes nomor 7 meminta siswa untuk menjumlahkan bilangan 196 dan 169. Operasi hitung pada soal tes nomor 7 ini merupakan penjumlahan dengan teknik menyimpan. Jawaban yang sesuai dengan pertanyaan tersebut adalah 365. Hasil temuan yang diperoleh, terdapat 5 siswa diantaranya 2 siswa perempuan dan 3 siswa laki-laki yang keliru dalam menyelesaikan operasi hitung tersebut.

Wawancara dilakukan kepada 2 subjek yang keliru dalam menjawab masing-masing 1 siswa perempuan dan 1 siswa laki-laki. Subjek tersebut kemudian dikodekan dengan G1 untuk siswa perempuan dan G2 untuk siswa laki-laki. Hasil wawancara dengan subjek G1 ditemukan alasan kekeliruan dalam menyelesaikan operasi hitung tersebut yaitu lupa menjumlahkan "simpanan" dari satuan 6 dan satuan 9, karena $6+9=15$ yang kemudian menyimpan 1 untuk dijumlahkan dengan puluhan 9 dan puluhan 6 . Kemudian alasan subjek G2 keliru dalam menyelesaikan operasi hitung tersebut karena subjek G2 kurang paham dalam penjumlahan dengan teknik menyimpan sehingga satuan 6 ditambah dengan satuan 9 hasilnya 15 yang kemudian ditulis semuanya, bukan menyimpan 1 di atas ruas puluhan. Hal tersebut menunjukkan bahwa subjek G1 dan subjek G2 kurang matang pada konsep penjumlahan dengan teknik menyimpan sehingga mengalami diskalkulia indiagnostic.

Tabel 8. Soal dan jawaban tes nomor 8

\begin{tabular}{clc}
\hline $\begin{array}{c}\text { No. } \\
\text { Soal } \\
\text { Tes }\end{array}$ & Pertanyaan & Jawaban \\
\hline 8 & $\begin{array}{l}\text { Selesaikan } \\
\text { operasi hitung } \\
\text { dari } 183-138 !\end{array}$ & 45 \\
\hline
\end{tabular}


Untuk pertanyaan dan jawaban yang bernilai benar untuk soal tes nomor 8 ditunjukkan pada Tabel 8. Soal tes nomor 8 meminta siswa untuk mengurangkan bilangan 183 dengan 138. Operasi hitung pada soal tes nomor 8 ini merupakan pengurangan dengan teknik meminjam. Jawaban yang sesuai dengan pertanyaan tersebut adalah 45 . Hasil temuan yang diperoleh, terdapat 4 siswa diantaranya 1 siswa perempuan dan 3 siswa laki-laki yang keliru dalam menyelesaikan operasi hitung tersebut.

Kemudian dilakukan wawancara kepada 2 subjek yang keliru dalam menjawab masing-masing 1 siswa perempuan dan 1 siswa laki-laki. Subjek tersebut kemudian dikodekan dengan $\mathrm{H} 1$ untuk siswa perempuan dan $\mathrm{H} 2$ untuk siswa laki-laki. Hasil wawancara dengan subjek $\mathrm{H} 1$ ditemukan alasan kekeliruan dalam menyelesaikan operasi hitung tersebut yaitu terbalik dalam mengurangkan satuan 3 dengan satuan 8, karena dianggap 3 tidak bisa dikurangi 8 maka diselesaikan dengan dibalik yaitu 8 dikurangi 3 menghasilkan 5. Selanjutnya alasan subjek H2 keliru dalam menyelesaikan operasi hitung tersebut karena subjek H2 meminjam 1 dari puluhan 8 kemudian dijumlahkan dengan satuan 3 sehingga menjadi 4 padahal seharusnya ketika menggunakan teknik meminjam maka nilai satuan 3 menjadi 13. Hal tersebut menunjukkan bahwa subjek H1 dan subjek $\mathrm{H} 2$ kurang matang pada konsep pengurangan dengan teknik meminjam sehingga mengalami diskalkulia indiagnostic.

Berdasarkan hasil penelitian tersebut kesulitan belajar matematika yang dialami oleh siswa laki-laki dan siswa perempuan sama diantaranya kesulitan dalam membandingkan bilangan yang memiliki nilai lebih besar dan sebaliknya, dan kesulitan untuk mengingat konsep operasi bilangan yang sudah dipelajari. Hal tersebut senada dengan hasil penelitian (Aminah, Kurniawati, \& Riska, 2018) yang menyebutkan bahwa siswa perempuan mengalami kesulitan dalam menentukan operasi pengerjaan, namun untuk siswa laki-laki mengalami kesulitan dalam memahami soal.

\section{KESIMPULAN DAN SARAN}

Kesulitan belajar matematika atau yang biasa disebut sebagai diskalkulia dialami oleh $20 \%$ siswa perempuan dan $12,5 \%$ siswa laki-laki di kota Malang pada usia sekolah dasar. Jenis diskalkulia yang ditemukan pada siswa perempuan dan siswa laki-laki sama yaitu diskalkulia proctagnostic dan diskalkulia indiagnostik. Hasil tes menunjukkan bahwa persentase jawaban yang paling banyak terjadi kekeliruan adalah jawaban dari siswa perempuan.

Diharapkan guru memantau proses belajar di kelas dengan baik dan sering mengadakan penilaian agar siswa yang mengalami kesulitan belajar matematika dapat segera diketahui dan dibuatkan suatu cara berlatih yang sesuai agar bisa mengikuti materi yang diberikan oleh guru dengan baik. Orang tua juga diharapkan selalu mendampingi anak-anak di rumah dalam kegiatan belajar agar mengetahui kesulitan yang dialami oleh anakanaknya sehingga cara belajarnya dapat disesuaikan dengan kesulitan anak-anak diskalkulia tersebut.

\section{DAFTAR PUSTAKA}

Aminah, Kurniawati, A., \& Riska, K. (2018). Analisis Kesulitan Siswa dalam Menyelesaikan Soal Cerita Matematika Topik Pecahan Ditinjau dari Gender. 
DOI: https://doi.org/10.24127/ajpm.v8i2.2057

\section{Jurnal Teori dan Aplikasi Matematika.}

Azhari, B. (2017). Identifikasi

Gangguan Belajar Dyscalculia

Pada Siswa Madrasah

Ibtidaiyah.Al Khawarizmi: Jurnal

Pendidikan Dan Pembelajaran

Matematika, 1(1), 60-74.

Bintoro, F. A., \& Wijiastuti, A. (2016).

Prevalensi Anak Kesulitan

Berhitung di SD: Asesmen

Matematika Berbasis

Kurikulum. Jurnal Pendidikan

Khusus.

Hall, J. (2012). Gender Issues in Mathematics : An Ontario

Perspective. Journal of Teaching And Learning, 8(1), 59-72.

Iftayani, I. (2018). Profil Kesulitan

Belajar Matematika dan

Kecenderungan Diskalkulia Pada

Siswa Sekolah Dasar di Purworejo.

SemNasPsi (Seminar Nasional

Psikologi), 1(1), 41-52.

Kenedi, A. K., Helsa, Y., Ariani, Y., Zainil, M., \& Hendri, S. (2019).

Mathematical Connection Of Elementary School Students To Solve Mathematical Problems. Journal on Mathematics Education, 10(1), 69-80.

Leder, G. C., Forgasz, H. J., \& Jackson, G. (2014). Mathematics , English and Gender Issues: Do Teachers Count? Australian Journal of Teacher Education, 39(9).

MZ, Z. A. (2018). Perspektif Gender Dalam Pembelajaran Matematika. Marwah: Jurnal Perempuan, Agama Dan Jender, 12(1), 15. https://doi.org/10.24014/marwah.v

\section{$12 \mathrm{i} 1.511$}

Nasser, A. (2016). The Difference Between Girls and Boys in Learning. Defense Language Institute Foreign Language School, 1(December). https://doi.org/10.1080/14616734.2 018.1428997

Nfon, N. F. (2016). a Survey of the Mathematical Problems (Dyscalculia) Confronting Primary School Pupils in Buea Municipality in the South West Region of Cameroon. International Journal of Education and Research, 4(4), 437-450.

Raharjo, T., Kawuryan, F., \& Ahyani, L. N. (2011). Identifikasi Learning Disability Pada Anak Sekolah Dasar. Jurnal Sosial dan Budaya, 136-142.

Rahman, M. (2016). Pendidikan Keluarga Berwawasan Gender Pada Anak Berkebutuhan Khusus di Kudus. PALASTREN, 9(1), 137-160.

Sudha, P., \& Shalini, A. (2014). Dyscalculia: A Specific Learning Disability Among Children. International Journal of Advanced Scientific and Technical Research, 2(4), 912-918.

Trieni, P. (2018). The Difficulties Of Students In Learning Mathematics By Using Development Learning Sequences Approach In SD Negeri No. 08 Koto Berapak Kecamatan Bayang. Jurnal Ilmiah Pendidikan Scholastic, 2(1), 39-49. 